\title{
Using and Experiencing the Academic Library: A Multisite Observational Study of Space and Place
}

\section{Francine May and Alice Swabey}

This study examines how students are using academic library spaces and the role these spaces are playing in the campus community. Data were collected on five campuses (two community colleges, two undergraduate universities, and one technical institute) via observational seating sweeps and questionnaires. The study found remarkably similar usage patterns across all library types. Academic pursuits remain the most common activities, despite perceptions of the modern library as a social space. The library as a place to study is shown to be a complex topic, with noise, need, and personal preference influencing experience. The research provides libraries with evidence to demonstrate their support of student learning and engagement within their institutions.

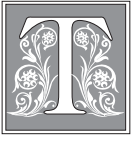

ransformations in the academic landscape, including the format and availability of information and new approaches to teaching, mean the role of the academic library is in flux. As Martell reports, virtual access is the preferred method for accessing information in postsecondary institutions, a fact that might lead some to call into question the very existence of the library as a physical entity. ${ }^{1}$ John Regazzi reports that, between 1998 and 2010, although there were large drops in reference and circulation statistics at most of over 3,000 academic libraries examined, there was comparatively little change in the number of physical visits to these same spaces. ${ }^{2}$ These changing statistics highlight questions about the role that academic libraries as physical spaces play in the academic community. This reason, in addition to tightening financial constraints and the resulting increase in pressure to prove value to the larger academic community, makes studying the academic library as place a timely and useful topic.

Scott Bennett reviews the evolution of the library in terms of several paradigm changes, from a reader-centered space where books were scarce, then, as accessibility of printed material exploded, to a book-centered space designed primarily to house materials. ${ }^{3}$ Now the digital age returns us to a time when storage of physical materials becomes secondary; but, instead of a return to a reader-centered paradigm, Bennett advocates embracing a learner-centered approach. ${ }^{4}$ After reviewing articles that consider the role of the library in the academic community, Danuta Nitecki concludes that

Francine May and Alice Swabey are Associate Professors at Mount Royal University; e-mail: fmay@ mtroyal.ca, aswabey@mtroyal.ca. (C2015 Francine May and Alice Swabey, Attribution-NonCommercial (http://creativecommons.org/licenses/by-nc/3.0/) CC BY-NC. 
there are three roles for libraries: that of "accumulator" (for example, of books and equipment); that of "service provider" (such as retrieving information or providing instruction); and that of "facilitator." 5 The role of facilitator links closely to Bennett's learner-centered approach and refers to the design of a physical or virtual environment that fosters connections among individuals (whether students, faculty, or staff), supports self-directed learning, and facilitates the creation of new knowledge.

To some extent, libraries have embraced this outlook and made student learning an important consideration when designing physical spaces. ${ }^{6}$ Recent studies have examined how successful these modern spaces are in supporting student learning. Charles Crook and Gemma Mitchell examined a library space designed for group work with access to supportive technology. Their findings indicated that a significant proportion of the users of that space were not using it as had been intended by the design. In other words, they were either involved in no social interaction, were not using the technology provided, and/or were engaged in no study activity whatsoever. ${ }^{7}$ Numerous studies have shown that students appear to like doing individual research in areas designed for social, noisier academic group work. ${ }^{8}$ In spite of this, both Montgomery and Suarez found that, for more "serious" study, students would choose other, more private library locations to work. ${ }^{9}$ Such studies tell us that there is still much to learn about how library spaces support learning and how we can design these spaces effectively.

Lawrence Paretta and Amy Catalano observed students using an academic library to determine what activities they were engaged in. ${ }^{10}$ Their results indicate that close to 60 percent of activities observed were study related, such as reading, typing, or visiting Blackboard. Although computers were heavily used for study-related activities such as looking at online library materials and typing documents, the students using them were more likely to be engaged in non-study-related behaviors, such as looking at noneducational websites, than individuals who were not using a computer. Other researchers have found that, while in the library, students are likely to engage in both academic and social pursuits, often simultaneously. ${ }^{11}$ Academic work remains their primary activity, however; Foster found that academic vs. recreational activities happened at a ratio of 6:1 in the library, while Suarez observed that, even with their flirting, chatting, and other social endeavours, students in the library are engaged in academic work most of the time. ${ }^{12}$ Students have repeatedly indicated that they want library spaces to support both academic and social activities, and these researchers conclude that the library succeeds in fulfilling these disparate roles.

When examining library spaces, one cannot ignore the topic of noise. This issue is significant for academic libraries; despite the increasingly collaborative nature of academic work, students still want and need quiet. Jeffrey Gayton concluded that what library patrons "find most useful and appealing are communal spaces that encourage serious study," defining communal activity as solitary and contemplative but in the company of others, and sitting in direct conflict with the social spaces found in many modern academic libraries. ${ }^{13}$ This conflict can become tangible when social areas are located in close proximity to quiet study areas, according to Bedwell and Banks, who found that such arrangements sometimes resulted in aggressive behaviours. ${ }^{14}$ YooLee, Lee, and Velez conclude that, although both group and solo spaces in libraries are well used, and in spite of students' appreciation for the flexibility and opportunity provided by these spaces, students still "consider the quiet communal spaces integral to their experience of the library."15 This perception of the library and its illustration of students' need for contemplative space is a common refrain in the literature. ${ }^{16}$ Vondracek found that quiet is a key driver for students choosing a place to study alone, with noise a leading deterrent for students who choose not to use the library to study. ${ }^{17}$ Gordon-Hickey and Lemley show that, for some library users, the need for quiet is 
physiologically based and that this need is more widespread than modern thinking in the collaborative academic setting might suggest. ${ }^{18}$ Noise, then, remains a divisive issue and one worth exploring in the academic library environment.

\section{Research Question}

A review of the literature gives us an idea of what we want the library to be and tells us something about student desires for these spaces, but it leaves us with questions about what is currently happening in these spaces. Many studies, such as those by Paretta and Catalano, Howard Silver, and Kathleen Webb, Molly Schaller, and Sawyer Hunley, while expertly executed, examine this topic from the perspective of individual libraries, making generalizations more difficult. ${ }^{19}$ Yoo-Lee, Lee, and Velez, in their single site study, acknowledged the need for "more factual information from multiple end users' perceptions and use of library spaces" and called for library researchers to seek more multisite study opportunities to validate the findings of existing research. ${ }^{20}$ Against this background, our paper explores the actual use of physical space in academic libraries serving three distinct types of institutions: community colleges, undergraduate universities, and a technical institute. We present the results of this study examining the use and meaning of space in five Canadian academic libraries.

\section{Methods}

This study examines student use of five small to medium academic libraries in Canada. Institutions varied in size from four to twelve thousand (full-time equivalent) students and included two community colleges, Lethbridge (LC) and Red Deer (RD) (smaller regional institutions offering primarily vocational programs and programs to prepare students for further study); two undergraduate universities, Grant MacEwan (GM) and Mount Royal (MR) (larger urban institutions offering bachelor's degrees and some twoyear certificate programs); and a technical college, Southern Alberta Institute of Technology (ST) (larger urban institution focusing on technical and vocational programs) (see table 1). Study libraries were selected both for variety and geographic convenience.

Data collection coincided with what are traditionally the busiest times of the year for the study libraries. We gathered data during the 2009-2010 academic year via seating sweeps and student questionnaires (see appendices A and B). Seating sweeps are a method of unobtrusive observation that produce detailed, quantifiable information about the use of library spaces (for a description of this method, see Lisa Given and Gloria Leckie, 2003). Human research ethics approval was received from each of the five institutions involved. Preliminary results were presented at the 9th Annual Northumbria International Conference on Performance Measurement in Libraries and Information Services and printed in the resulting proceedings. ${ }^{21}$

We conducted rounds of seating sweeps twice at each library, once in the middle of the fall semester and once mid-winter. Each round of seating sweeps involved four separate sweeps of the library on a single day (morning, midday, afternoon, and evening). During these sweeps, observers recorded the location, possessions, and activities of each individual observed. In total, 9,268 individuals were observed during the seating sweeps (GM 3,141, MR 2,077, LC 712, RD 1,711, and ST 1,627). In areas where it was not feasible to make detailed individual observations, stratified sampling was used, with basic information gathered about all individuals and detailed observations only recorded for every fifth person.

We circulated questionnaires to individuals in the library during the midwinter visit, on the day following the seating sweeps. In larger libraries (GM, MR), a stratified sampling technique was used in high-density areas (for example, in a crowded computer lab only the individual located at every third occupied seat was invited to complete 


\begin{tabular}{|c|c|c|c|c|c|}
\hline \multicolumn{6}{|c|}{$\begin{array}{c}\text { TABLE } 1 \\
\text { Comparative Descriptive Statistics }(2009-2010) \text { of the Five Study Libraries }\end{array}$} \\
\hline & GM & MR & $\mathbf{L C}$ & RD & ST \\
\hline $\begin{array}{l}\text { FLE }^{\dagger} \\
\text { (Full Load Equivalent*) }\end{array}$ & 11,156 & 9,670 & 4,123 & 4,001 & 11,645 \\
\hline Total Seats/FLE & 0.119 & 0.057 & 0.051 & 0.127 & 0.038 \\
\hline Computer Seats/FLE & 0.044 & 0.008 & 0.058 & 0.056 & 0.01 \\
\hline $\begin{array}{l}\text { Group Study Room Seats/ } \\
\text { FLE }{ }^{\ddagger}\end{array}$ & 0.019 & 0.002 & 0.007 & 0.019 & 0.004 \\
\hline Gate Count/FLE & No Data & 96 & 185 & 143 & 46 \\
\hline Volumes/FLE & 27 & 29 & 12 & 34 & 8 \\
\hline Circulations/FLE Student & 16 & 12 & 4 & 16 & 2 \\
\hline $\begin{array}{l}\text { Reference Transactions/ } \\
\text { FLE Student/ Year }\end{array}$ & 4 & 4 & No Data & 7 & 2 \\
\hline $\begin{array}{l}\text { Number of Students } \\
\text { Receiving Information } \\
\text { Literacy Instruction/FLE }\end{array}$ & 1.1 & 2.3 & 0.7 & 0.7 & 0.2 \\
\hline \multicolumn{6}{|c|}{$\begin{array}{l}\text { *FLE is a method of comparing enrollment across institutions. This unit of measurement } \\
\text { is the equivalent of a student taking a standard full course load during an academic year. } \\
\text { Students who take less than a full course load generate less than one full FLE. }\end{array}$} \\
\hline \multicolumn{6}{|c|}{$\begin{array}{l}\text { Sources: } \\
{ }^{\dagger} \text { MR Office of Institutional Analysis and Planning } \\
{ }^{*} \text { Alberta Association of Academic Librarians Statis }\end{array}$} \\
\hline
\end{tabular}

the questionnaire); but, in smaller libraries (LC, RD and ST), all patrons in the library were invited to complete the questionnaire. At the first library (LC), questionnaires were distributed both in print and electronically. For those who were given a choice, preference was much stronger for the paper questionnaire and response rates were also much higher: 87 percent $(n=71)$ of paper questionnaires at LC were completed but only 43 percent $(n=31)$ of electronic. Subsequently, only paper questionnaires were distributed. Response rates were as follows: ST 85 percent $(n=134)$, GM 89 percent $(n$ $=123), \operatorname{RD} 81$ percent $(n=122)$, MR 85 percent $(n=127)$. Combined response rate for all five institutions was 83 percent. Only a very few respondents identified themselves as being anything other than a student; due to the extremely low numbers, these responses were discarded.

\section{Practical Limitations}

The strength of the seating sweep method is the ability to survey and observe many student users of the library and to repeat the sweeps at different times of the day. This strength is also a limitation, as it overemphasizes activities that take longer to accomplish. A sweep captures a snapshot in time, and people engaging in more timeconsuming activities will inevitably spend more time doing them and so be more likely to be recorded doing those activities. This method is also limited to collecting superficial observations of library users. In addition, neither the seating sweep nor the questionnaire allow for clarification or follow-up. For example, some of the issues that were raised in the questionnaires to do with preferences for noise or quiet would have benefited from a deeper exploration such as would have been possible if focus 
groups or interviews had been employed. Ethnography, which has become popular in user behavior studies, can allow for the collection of deeper-though generally less abundant - data and more nuanced observation. However, such methods were beyond the human resource means of our small research team, and we chose our method in large part due to our desire to observe a large number of users at multiple sites. Finally, although we are unable to claim that our study is statistically generalizable, we believe we have taken a step in the right direction by conducting a multisite study of different library types and including a large number of library users.

\section{Results and Discussion}

\section{Who Is Using These Libraries and How Often?}

Our observations indicate that males are somewhat more likely to use the physical library than females. When averaged over the five institutions, females were observed in the physical library less (by 7\%) than one would have expected based on the ratio of students enrolled, though the numbers varied by institution, with several institutions showing a small positive difference (see table 2). This corresponds with other research that has also found males to be overrepresented in terms of physical library use as compared to their percentage of the student population. ${ }^{22}$ Most questionnaire respondents were under the age of 25 and had been studying at the institution for two years or less (data not shown). This reflects the preponderance of two-year diploma and university programs at the institutions examined.

\begin{tabular}{|c|c|c|c|c|c|c|}
\hline \multicolumn{7}{|c|}{$\begin{array}{c}\text { TABLE } 2 \\
\text { Gender of Questionnaire Respondents and Individuals Observed during } \\
\text { Seating Sweeps }(\%)\end{array}$} \\
\hline & $\begin{array}{c}\text { GM } \\
(n=125)\end{array}$ & $\begin{array}{c}\mathrm{LC} \\
(\mathrm{n}=104)\end{array}$ & $\begin{array}{c}\text { MR } \\
(n=130)\end{array}$ & $\begin{array}{c}\text { RD } \\
(n=131)\end{array}$ & $\begin{array}{c}\text { ST } \\
(n=135)\end{array}$ & $\begin{array}{c}\text { Total } \\
(n=622)\end{array}$ \\
\hline \multicolumn{7}{|c|}{ Gender of Questionnaire Respondents } \\
\hline $\mathrm{F}$ & $49 \%$ & $61 \%$ & $59 \%$ & $61 \%$ & $53 \%$ & $57 \%$ \\
\hline M & $50 \%$ & $37 \%$ & $36 \%$ & $36 \%$ & $43 \%$ & $40 \%$ \\
\hline \multicolumn{7}{|c|}{ Gender of Individuals Observed in the Library } \\
\hline $\mathrm{F}$ & $49 \%$ & $53 \%$ & $56 \%$ & $58 \%$ & $39 \%$ & $51 \%$ \\
\hline M & $50 \%$ & $47 \%$ & $44 \%$ & $41 \%$ & $61 \%$ & $49 \%$ \\
\hline \multicolumn{7}{|c|}{ Male/Female Ratio (\%) at Each Institution* } \\
\hline $\mathrm{F} / \mathrm{M}$ & $64 / 36$ & $62 / 38$ & $52 / 48$ & $56 / 44$ & $57 / 43$ & $58 / 42$ \\
\hline \multicolumn{7}{|c|}{ Difference between Percentage of Females Enrolled and Observed in Library } \\
\hline $\begin{array}{l}\text { Difference } \\
\text { (Negative) }\end{array}$ & $(15)$ & (9) & 4 & 2 & (18) & (7) \\
\hline
\end{tabular}

The library occupies a prominent place in the timetable of most questionnaire respondents, with the majority visiting the library several times a week or more (see table 3) and for extended periods of time (see figure 1). Questionnaire respondents self-report fairly strong grades, with over half reporting a GPA (grade point average) between 2.7 and 3.6 (correlates to a letter grade of " $\mathrm{B}$ " and the second highest of the five letter grade categories possible) (data not shown). The second most common grade was an " $\mathrm{A}$ " (GPA of between 3.7 and 4, the highest letter grade possible). This pattern was the same 
for all institutions. It is not possible to say how accurate these numbers are, due to the fact that they are self-reported. Frequency of visits to the library does not appear to be related to self-reported GPA (see figure 2), a finding that is confirmed by other studies. ${ }^{23}$

\section{How Do Students Make Use of Library Spaces?}

Students report engaging in a wide variety of activities in the study libraries (students could select multiple activities; see table 4). Responses can be grouped into the following (overlapping) categories: completing academic work, engaging in social activities, using print materials, and accessing the service desks/borrowing materials. Many of

TABLE 3

Reported Frequency of Visits to the Library by Questionnaire Respondents

\begin{tabular}{|l|c|c|c|c|c|c|}
\hline Frequency & $\begin{array}{c}\text { GM } \\
(\mathbf{n = 1 2 5})\end{array}$ & $\begin{array}{c}\mathbf{L C} \\
(\mathbf{n}=\mathbf{1 0 4})\end{array}$ & $\begin{array}{c}\text { MR } \\
(\mathbf{n}=\mathbf{1 3 0})\end{array}$ & $\begin{array}{c}\mathbf{R D} \\
(\mathbf{n}=\mathbf{1 3 1})\end{array}$ & $\begin{array}{c}\mathbf{S T} \\
(\mathbf{n}=\mathbf{1 3 5})\end{array}$ & $\begin{array}{c}\text { Total } \\
(\mathbf{n}=\mathbf{6 2 2})\end{array}$ \\
\hline $\begin{array}{l}\text { At Least Once per } \\
\text { Day }\end{array}$ & $35 \%$ & $21 \%$ & $30 \%$ & $38 \%$ & $30 \%$ & $31 \%$ \\
\hline $\begin{array}{l}\text { Several Times a } \\
\text { Week }\end{array}$ & $43 \%$ & $42 \%$ & $31 \%$ & $34 \%$ & $50 \%$ & $40 \%$ \\
\hline Once a Week & $9 \%$ & $16 \%$ & $19 \%$ & $7 \%$ & $11 \%$ & $12 \%$ \\
\hline $\begin{array}{l}\text { Once a Month or } \\
\text { Less }\end{array}$ & $7 \%$ & $2 \%$ & $7 \%$ & $4 \%$ & $3 \%$ & $5 \%$ \\
\hline It Varies & $0 \%$ & $20 \%$ & $13 \%$ & $12 \%$ & $4 \%$ & $10 \%$ \\
\hline Other & $6 \%$ & $0 \%$ & $0 \%$ & $6 \%$ & $2 \%$ & $3 \%$ \\
\hline
\end{tabular}

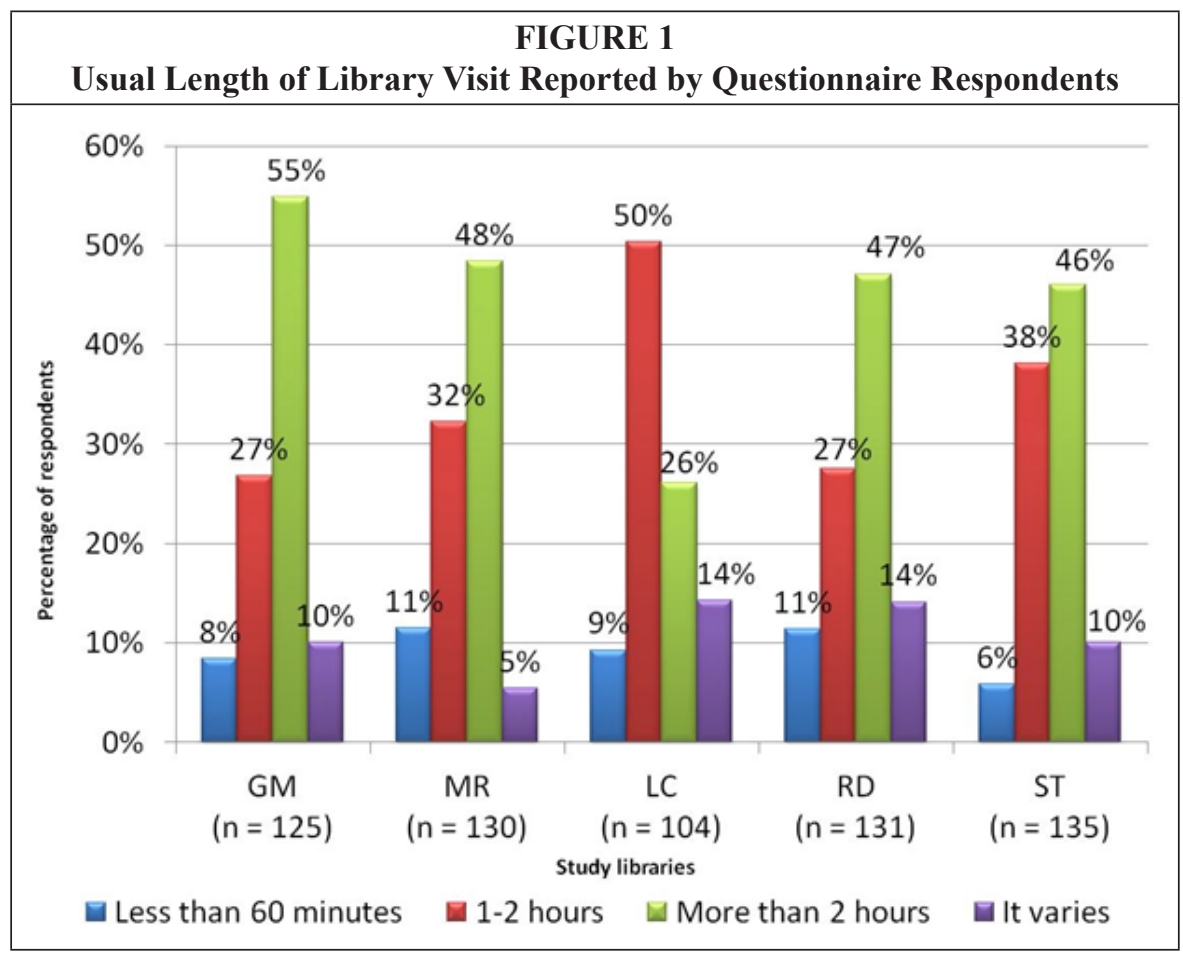




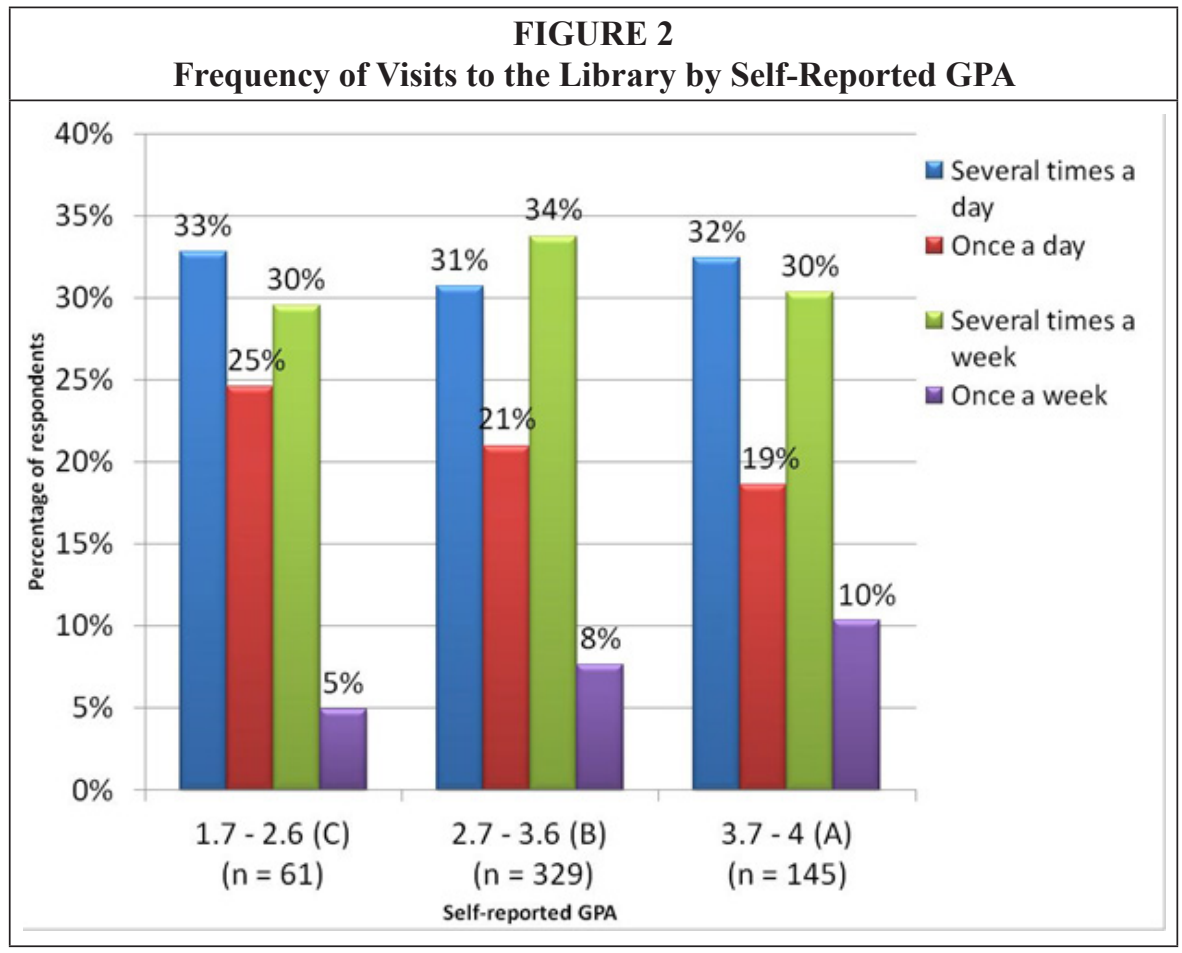

\begin{tabular}{|l|c|}
\hline \multicolumn{2}{|c|}{ TABLE 4 } \\
Activities Done in the Library by Questionnaire Respondents in the Past Year \\
\hline Activities & $\begin{array}{c}\text { Responses (\%) } \\
(\mathrm{n}=622)\end{array}$ \\
\hline Worked on academic work using the library computers & $84 \%$ \\
\hline Worked on academic work using a laptop & $82 \%$ \\
\hline Used the printers/photocopiers & $82 \%$ \\
\hline Socialized in person (that is, chatting with friends) & $75 \%$ \\
\hline Drank & $75 \%$ \\
\hline Ate & $69 \%$ \\
\hline Socialized online (for example, by using Facebook or e-mail) & $68 \%$ \\
\hline Used a group study room & $67 \%$ \\
\hline Got help from library staff & $63 \%$ \\
\hline Read or studied print materials NOT FROM THE LIBRARY & $60 \%$ \\
\hline Borrowed or returned library materials & $54 \%$ \\
\hline Physically searched for information (that is, in the bookshelves) & $50 \%$ \\
\hline Read or studied print materials FROM THE LIBRARY & $46 \%$ \\
\hline Attended a library instruction session or workshop or tour & $36 \%$ \\
\hline Took a nap & $30 \%$ \\
\hline
\end{tabular}


the reported activities are directly linked to the academic purpose of the library, while others have a more tenuous connection. Unsurprisingly, technology continues to be an important part of the library experience, as respondents overwhelmingly reported using computers, laptops, photocopiers, and printers in the library. Previous research has found that, on average, students had three different purposes for visiting the library on a given day with top reasons similar to those reported here. ${ }^{24}$ When asked about the main activity that brought them to the library on the day they filled out the questionnaire, the most common responses were to use either a desktop or laptop computer or to read print material, whether from the library or material that they brought with them (see figure 3).

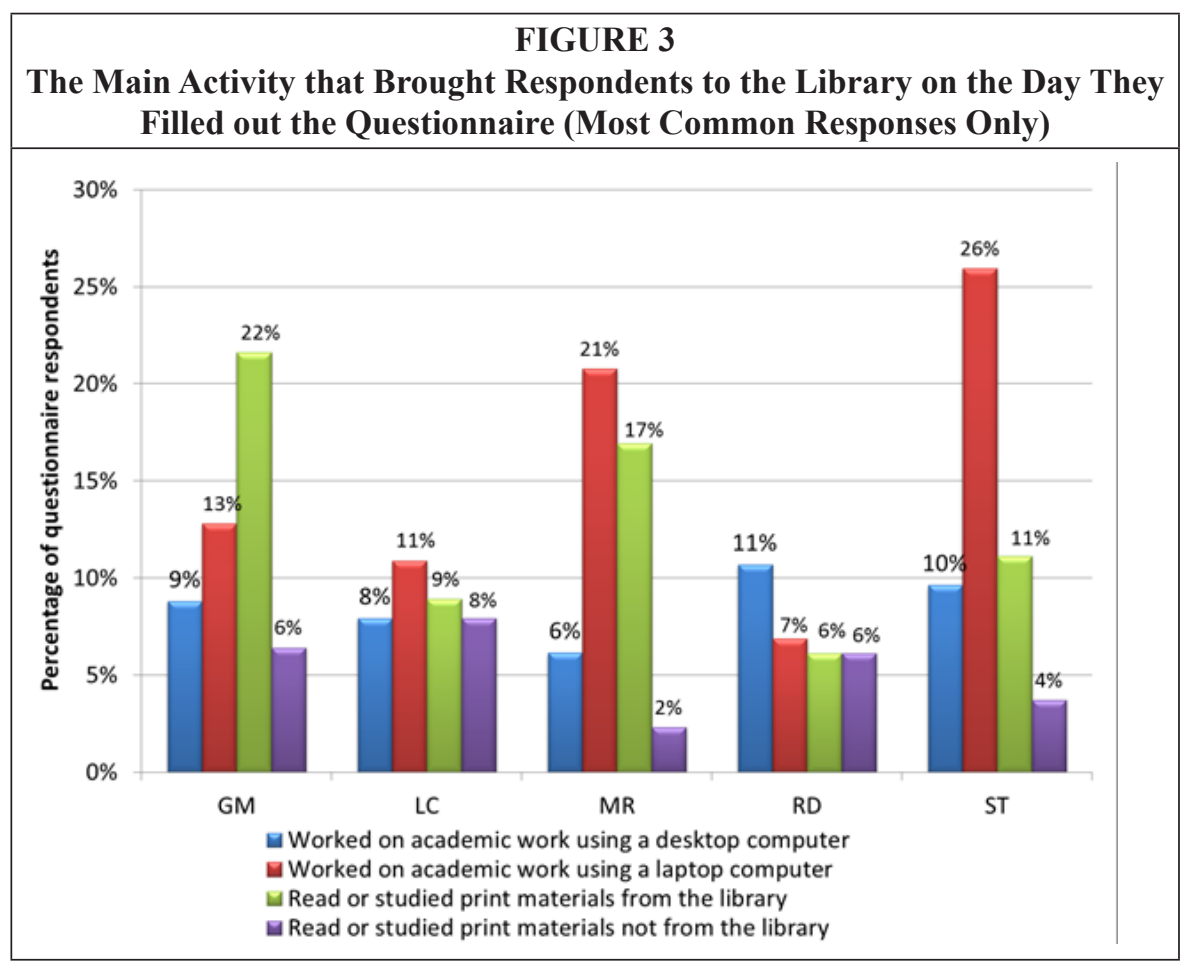

\section{Academic Work}

Whether working on a computer or with print materials, academic work is a key reason that brought students to the library on the day they filled out the questionnaire. Observations of student possessions and activities add further evidence to the studious nature of the activities taking place in these spaces. Although it is not possible to determine the exact nature of the activities observed, four of the top five activities (using a computer, either desktop or laptop, and reading and writing in print) are highly suggestive of academic work (see table 5). In addition, many individuals in the library were equipped with knapsacks or larger carry-all bags, print reading, or writing materials (see table 6).

Further emphasizing the academic importance of the library space, almost 40 percent of questionnaire respondents report completing over half of their out-of-class academic work in the library (see table 7). This number closely matches that reported by Silver, who found that students reported an average of 55 percent of their studying took 
Using and Experiencing the Academic Library 779

\begin{tabular}{|l|c|c|c|c|c|c|}
\hline \multicolumn{7}{|c|}{ TABLE 5 } \\
\hline Activities Observed in the Libraries \\
\hline $\begin{array}{l}\text { GM } \\
(\mathrm{n}=1,819)\end{array}$ & $\begin{array}{c}\text { LC } \\
(\mathrm{n}=610)\end{array}$ & $\begin{array}{c}\text { MR } \\
(\mathrm{n}=2,077)\end{array}$ & $\begin{array}{c}\text { RD } \\
(\mathrm{n}=915)\end{array}$ & $\begin{array}{c}\text { ST } \\
(\mathrm{n}=1,209)\end{array}$ & $\begin{array}{c}\text { Total } \\
(\mathrm{n}=6,046)\end{array}$ \\
\hline $\begin{array}{l}\text { Using Desktop } \\
\text { Computer }\end{array}$ & $20 \%$ & $37 \%$ & $20 \%$ & $25 \%$ & $31 \%$ & $27 \%$ \\
\hline Reading [in Print] & $30 \%$ & $21 \%$ & $15 \%$ & $11 \%$ & $30 \%$ & $24 \%$ \\
\hline $\begin{array}{l}\text { In Conversation, } \\
\text { Talking, Listening }\end{array}$ & $26 \%$ & $27 \%$ & $12 \%$ & $26 \%$ & $22 \%$ & $23 \%$ \\
\hline Using Laptop & $18 \%$ & $15 \%$ & $17 \%$ & $12 \%$ & $23 \%$ & $19 \%$ \\
\hline Writing [in Print] & $19 \%$ & $10 \%$ & $8 \%$ & $7 \%$ & $15 \%$ & $13 \%$ \\
\hline $\begin{array}{l}\text { Listening to } \\
\text { Headphones }\end{array}$ & $9 \%$ & $10 \%$ & $6 \%$ & $4 \%$ & $10 \%$ & $9 \%$ \\
\hline Using a Cell Phone & $6 \%$ & $2 \%$ & $3 \%$ & $5 \%$ & $3 \%$ & $4 \%$ \\
\hline $\begin{array}{l}\text { Physically Searching, } \\
\text { Retrieving, Browsing }\end{array}$ & $2 \%$ & $0 \%$ & $1 \%$ & $1 \%$ & $2 \%$ & $2 \%$ \\
\hline Drinking & $2 \%$ & $0 \%$ & $1 \%$ & $3 \%$ & $1 \%$ & $1 \%$ \\
\hline Eating & $2 \%$ & $1 \%$ & $1 \%$ & $2 \%$ & $1 \%$ & $1 \%$ \\
\hline Sleeping/Napping & $1 \%$ & $2 \%$ & $1 \%$ & $0 \%$ & $1 \%$ & $1 \%$ \\
\hline $\begin{array}{l}\text { Watching/Sitting/ } \\
\text { Contemplation }\end{array}$ & $1 \%$ & $0 \%$ & $1 \%$ & $2 \%$ & $1 \%$ & $1 \%$ \\
\hline Using Calculator & $0 \%$ & $0 \%$ & $0 \%$ & $1 \%$ & $1 \%$ & $1 \%$ \\
\hline $\begin{array}{l}\text { Using Library } \\
\text { Technology } \\
\text { Excluding Computers) }\end{array}$ & $1 \%$ & $2 \%$ & $0 \%$ & $0 \%$ & $1 \%$ & $1 \%$ \\
\hline
\end{tabular}

\begin{tabular}{|l|c|c|c|c|c|c|}
\hline \multicolumn{7}{|c|}{ TABLE 6 } \\
Percentage of Library Users Observed with Each Category of Possession \\
\hline Possession & $\begin{array}{c}\text { GM } \\
(\mathrm{n}=1,819)\end{array}$ & $\begin{array}{c}\text { LC } \\
(\mathrm{n}=610)\end{array}$ & $\begin{array}{c}\text { MR } \\
(\mathrm{n}=2,077)\end{array}$ & $\begin{array}{c}\text { RD } \\
(\mathrm{n}=915)\end{array}$ & $\begin{array}{c}\text { ST } \\
(\mathrm{n}=1,209)\end{array}$ & $\begin{array}{c}\text { Total } \\
(\mathrm{n}=6,046)\end{array}$ \\
\hline $\begin{array}{l}\text { Knapsack, Carryall } \\
\text { Bag }\end{array}$ & $80 \%$ & $79 \%$ & $57 \%$ & $47 \%$ & $81 \%$ & $75 \%$ \\
\hline $\begin{array}{l}\text { Reading Materials [in } \\
\text { Print] }\end{array}$ & $64 \%$ & $51 \%$ & $38 \%$ & $48 \%$ & $58 \%$ & $56 \%$ \\
\hline $\begin{array}{l}\text { Writing Materials } \\
\text { [Print], Pens, Paper... }\end{array}$ & $44 \%$ & $45 \%$ & $30 \%$ & $33 \%$ & $41 \%$ & $41 \%$ \\
\hline Drink & $33 \%$ & $20 \%$ & $21 \%$ & $24 \%$ & $21 \%$ & $27 \%$ \\
\hline Laptop Computer & $26 \%$ & $22 \%$ & $22 \%$ & $19 \%$ & $29 \%$ & $26 \%$ \\
\hline Cell Phone & $25 \%$ & $16 \%$ & $21 \%$ & $20 \%$ & $18 \%$ & $23 \%$ \\
\hline $\begin{array}{l}\text { Calculator/Other } \\
\text { Electronics }\end{array}$ & $7 \%$ & $3 \%$ & $5 \%$ & $5 \%$ & $14 \%$ & $8 \%$ \\
\hline Food & $9 \%$ & $6 \%$ & $5 \%$ & $10 \%$ & $4 \%$ & $7 \%$ \\
\hline $\begin{array}{l}\text { MP3 Player/Portable } \\
\text { Music Player }\end{array}$ & $7 \%$ & $4 \%$ & $8 \%$ & $3 \%$ & $4 \%$ & $7 \%$ \\
\hline
\end{tabular}


TABLE 7

The Percentage of Out-of-Class Academic Work Completed in the Library, as Reported by Questionnaire Respondents

\begin{tabular}{|l|c|c|c|c|c|c|}
\hline Percentage & $\begin{array}{c}\text { GM } \\
(\mathbf{n}=\mathbf{1 2 5})\end{array}$ & $\begin{array}{c}\mathbf{L C} \\
(\mathbf{n}=\mathbf{1 0 4})\end{array}$ & $\begin{array}{c}\text { MR } \\
(\mathbf{n}=\mathbf{1 3 0})\end{array}$ & $\begin{array}{c}\text { RD } \\
(\mathbf{n}=\mathbf{1 3 1})\end{array}$ & $\begin{array}{c}\mathbf{S T} \\
(\mathbf{n}=\mathbf{1 3 5})\end{array}$ & $\begin{array}{c}\text { Total } \\
(\mathbf{n}=\mathbf{6 2 2})\end{array}$ \\
\hline Less than $25 \%$ & $19 \%$ & $36 \%$ & $31 \%$ & $23 \%$ & $27 \%$ & $27 \%$ \\
\hline $26-50 \%$ & $33 \%$ & $32 \%$ & $36 \%$ & $31 \%$ & $38 \%$ & $34 \%$ \\
\hline $51-75 \%$ & $29 \%$ & $27 \%$ & $21 \%$ & $27 \%$ & $23 \%$ & $25 \%$ \\
\hline $76-100 \%$ & $18 \%$ & $5 \%$ & $12 \%$ & $18 \%$ & $11 \%$ & $13 \%$ \\
\hline No Response & $2 \%$ & $0 \%$ & $0 \%$ & $2 \%$ & $1 \%$ & $1 \%$ \\
\hline
\end{tabular}

place in the library. ${ }^{25}$ It is interesting to note that our data do not show a link between percentage of out-of-class academic work completed in the library and self-reported GPA (see figure 4).

\section{Social Activity and Food Consumption}

Close to one quarter of users observed were engaged in conversation (see table 5). It is not possible to know whether those conversations were academic in nature, but student comments on questionnaires indicate that the library serves as a place to engage in group study and also that some individuals come to the library to socialize. One respondent said she came to the library to "work on a project with my Spanish partner," for example, while another said she came to "socialize in person." Some respondents were concerned about the ban on food in some of the

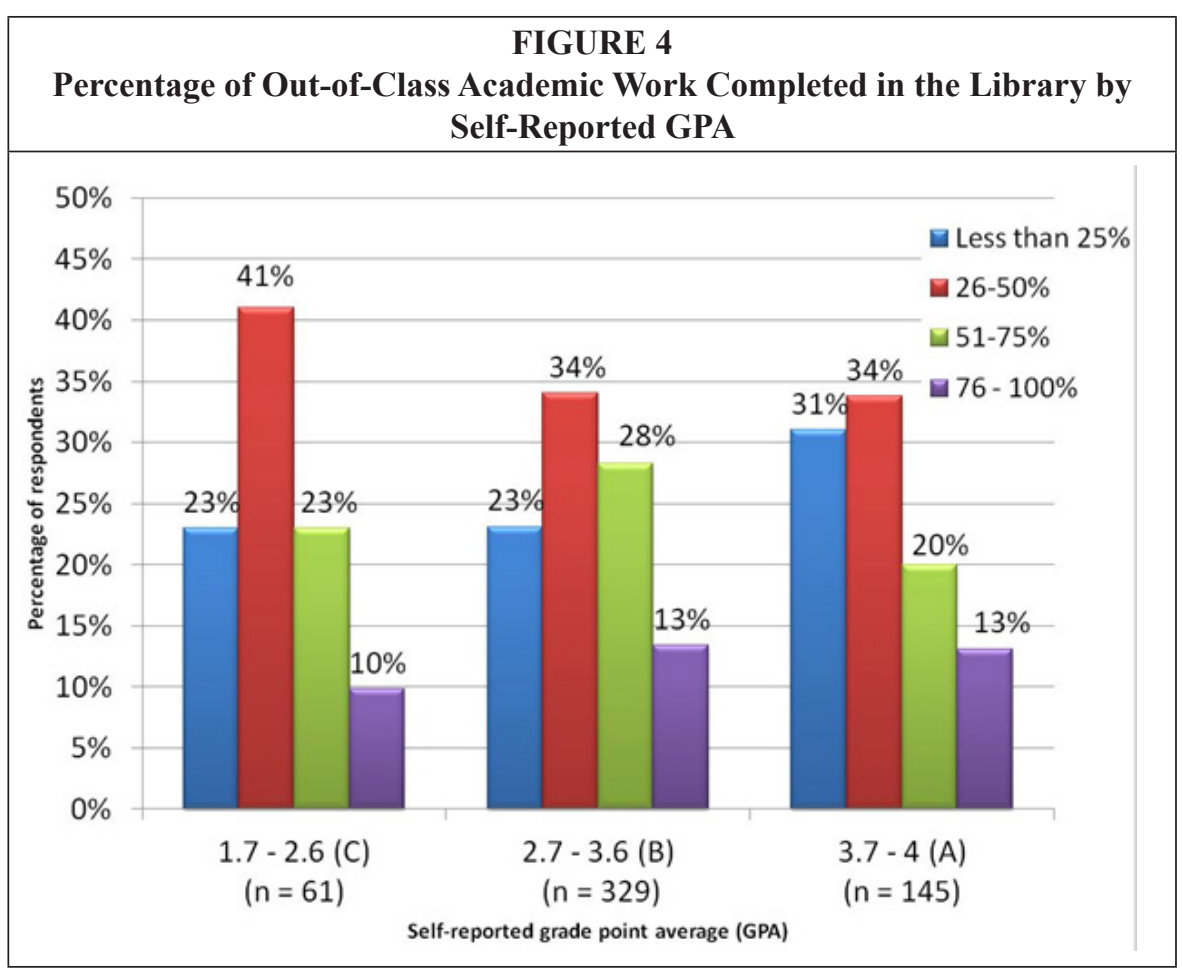


libraries, reflected in comments such as "please allow students to eat in the library but of course they need to be tidy" and "having to pack my book up and leave to eat and then return is annoying." It is interesting that policies allowing food in the library appeared to make little difference as to whether individuals were observed with food. GM, LC, and RD all allow food, and 9, 6, and 10 percent of individuals observed had food with them, numbers that are only a very slightly higher than MR (5\%) and ST (4\%), which have policies against eating in the library (see table $6)$. It may be that policies are not being enforced or that patrons are simply choosing not to follow them.

\section{Use of Technology}

Technology is of key importance to academic library users. Questionnaire responses show that use of a computer, whether desktop or laptop, was one of the most common reasons that students came to the library that day (see figure 3). Seating sweeps provide further evidence of the importance. Over one quarter of library users observed were using a desktop computer, and close to another fifth of users were using laptops (see table 5). This makes computer use by far the most frequently observed activity. This agrees with previous research, which indicates that computer usage is one of the most common activities for library users. ${ }^{26}$ Paretta and Catalano had reported on the higher probability that computer users would engage in nonacademic work than non-computer users; in the case of shared library computers, it seems that this has the potential to cause tension. ${ }^{27}$ As one student commented, "BAN FACEBOOK!!! When you can't find and need a computer, people are always on Facebook." Others wanted more computers but recognized the need to maintain a variety of spaces in the library: "There are a lot of computers, but most are usually full. More would be appreciated, but I wouldn't want desks for study to be sacrificed."

\section{Use of Print Materials}

Although users are more likely to be observed accessing a laptop or desktop computer, the use of print materials in these libraries is still common. Close to a quarter of individuals we observed were reading print materials, and another 13 percent were observed writing in print (see table 5). These numbers fall between results reported elsewhere. Paretta and Catalano report that the most common behavior was reading of academic print material, noted in 18.8 percent of students observed, ${ }^{28}$ while Anne Lehto, Leena Tolvonen, and Mirjna Iivonen report that 50 percent of students observed in the library were reading or writing (without computers). ${ }^{29}$

Print material supplied by the library remains an important resource for many students. One of the main activities that brought students to the library on the day of the questionnaire was to read or study print materials from the library, although this trend was much stronger at GM and MR (see figure 3). The focus on bachelor degree programs at these two institutions may be the reason that users appear to be making relatively heavy use of the library's print collections. It is possible that the variation could be explained by the mix of programs or assignments assigned at each institution or perhaps by the nature or size of the collections.

\section{Interaction with Service Desks/Browsing of Print Collection}

Compared to other locations in the library, we observed very few patrons in the library stacks $(1 \%)$ or at a service desk $(1 \%)$ (see figure 5$)$. These numbers confirm previous research, which found that some of the least occupied areas in the library included the book stacks and library service desks. ${ }^{30}$ These results may reflect the dropping circulation and reference statistics and/or the relatively shorter length of 


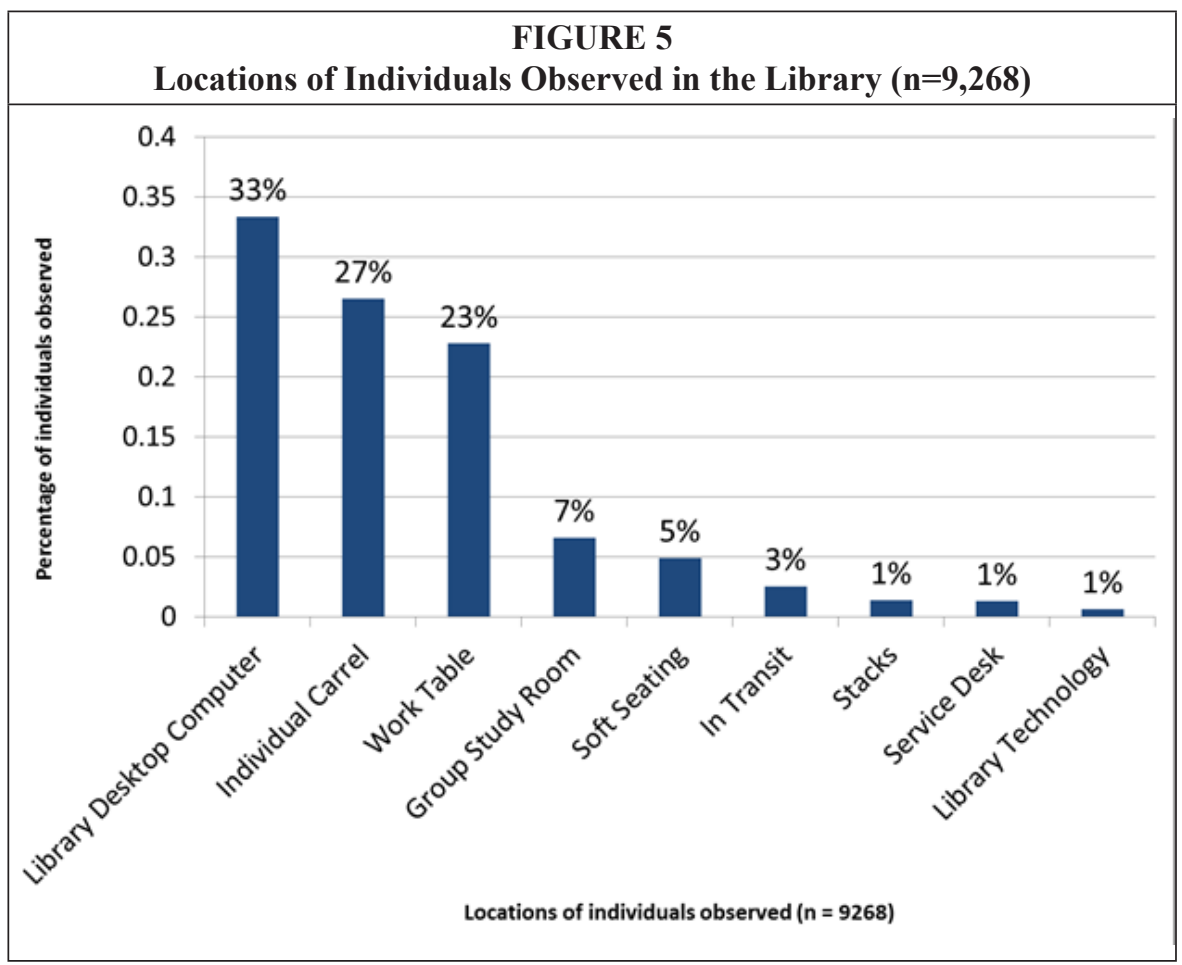

time it takes to conduct such transactions. A patron may spend five to ten minutes asking a reference question or finding a book and then study that book or use a computer for several hours. However, questionnaire responses indicate that users of these libraries do make use of the service desks: 63 percent of respondents indicated that they had sought help from library staff in the library over the past year (see table 4), library statistics indicate a range of 4-7 reference questions per FLE (see table 1), and at least one individual reported that she selected her seat in the library based on proximity to a help desk. Although patrons are less likely to be observed in these locations, this does not necessarily indicate that these services are not important to them. It may be, however, that they are playing a diminished role compared to their importance in the past.

\section{How Do Users Experience Library Spaces?}

Previous research has indicated that students have definite preferences for study space attributes, based on individual preference and/or the purpose that brings them to the library. ${ }^{31}$ Such research also indicates that library users can hold completely contradictory views of a space, either in the way they describe it (there is always a seat vs. there are never any seats available) or in their preferences (the library is better when it's quiet in the morning or it's best at lunch when there is a busy buzz of activity). In one study, students who liked studying in the library said it was because it was (among other things) quiet, comfortable, and without distractions. Conversely, in that same study, those who thought that same space was one of the worst places to study described it as noisy, quiet, uncomfortable, and distracting! ${ }^{32}$ Patrons experience the library in very individual ways, and the comments provided by questionnaire respondents surveyed for this study demonstrate this fact. 


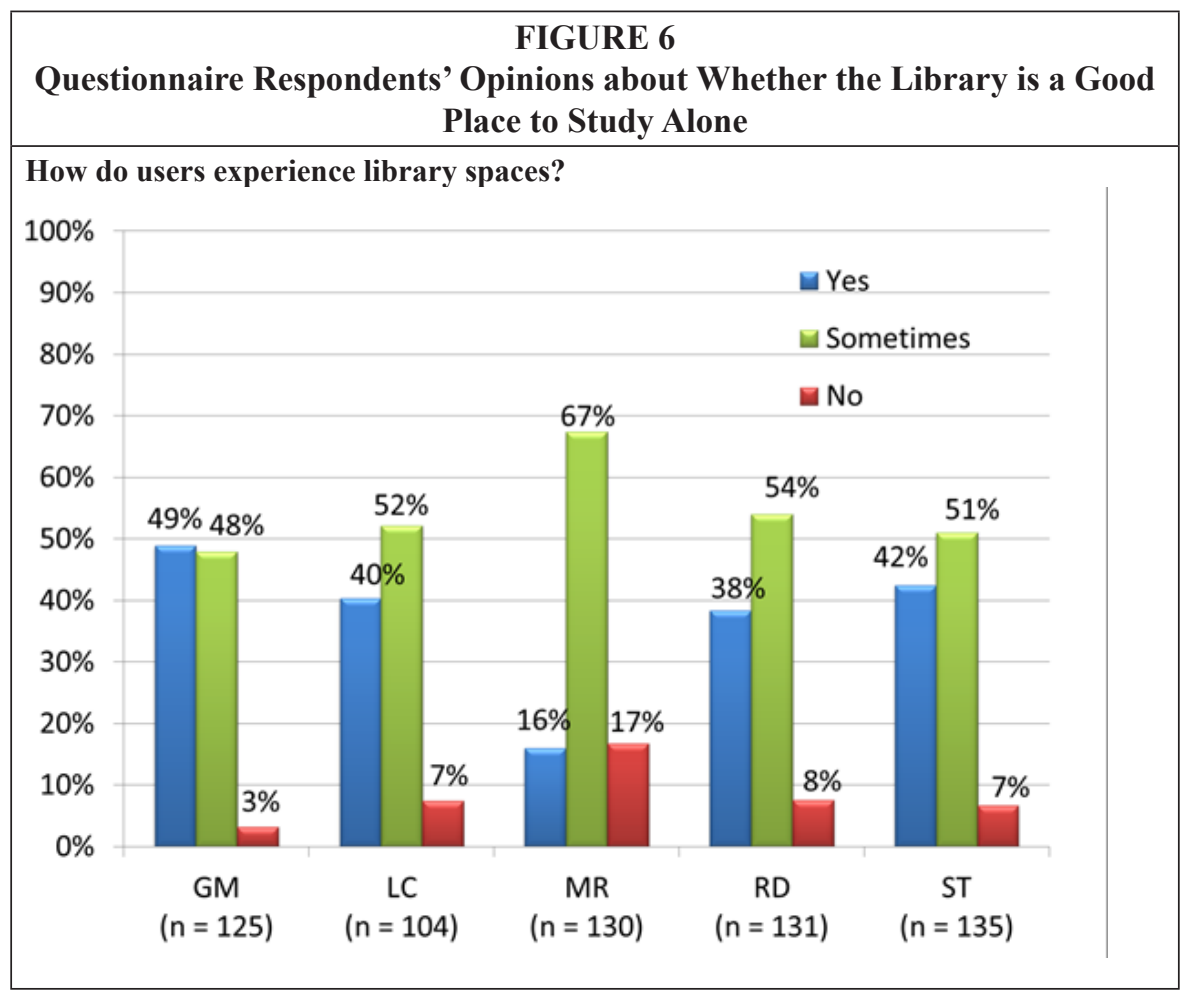

\section{The Library as a Place to Study Alone}

The answer to whether the library is a good place to study alone appears to be more complex than just "yes" or "no." When asked whether the library was a good place to study alone, over half of questionnaire respondents indicated that it sometimes was (see figure 6). Library usage at any institution varies with the time of day, day of the week, and time of the semester, a fact that offers a possible explanation for these responses.

Comments from those who had indicated that the library was only sometimes a good place to study alone grouped around a few main themes: noise, high occupancy levels, and interactions with other students (whether positive or negative). One respondent commented: "there's [sic] a lot of places to study alone but they're not always free." Others identified specific times of day (for example, the evening or the morning) when the library was a better place to work alone. MR head-counting statistics provide support for these statements, showing peak occupancy between 11 a.m. and 4 p.m., with Monday to Thursday being significantly busier than other days (Mount Royal University, unpublished data). Some complained about a lack of respect by students who were noisy when others around them were trying to study quietly: "even though the basement of the library is considered a quiet area it can get loud and people talk on their cell phones." Some respondents acknowledged that distractions were sometimes self-generated. One indicated that "sometimes I can't control myself to go on Facebook or some other websites" and another acknowledged that "sometimes it is loud, but I contribute!"

Particularly interesting responses in this category were from individuals who found that they profited from the communal study atmosphere created when people study together: 
"I often need motivation to continue. If I see others working hard, I work hard also, so often I come with a friend, and while we are both working independently, we are still together."

"I find it really helpful to have a 'study buddy,' someone studying with you, not necessarily on the same subject but focused on what they're doing".

Such responses support Gayton's stance that library users value the communal nature of academic libraries ${ }^{33}$ and $\mathrm{O}^{\prime}$ Connor's theory about "studying along" (as discussed by Bennett ${ }^{34}$ ), where students share a workspace but work independently.

When asked why they thought the library was a good or a bad place to study alone, respondents described the space in completely contradictory ways, a phenomenon that is not unique to this study. Many who cited the library as a good place to study alone indicated that it is a quiet place that promotes concentration. Although few respondents indicated that the library was not a good place to study alone, of those who did, by far the most common reason was due to the noise levels. It is possible that some of these individuals are only visiting the library during peak times and so are consistently finding it a noisy and crowded place. Noisy group areas of libraries are popular and thriving, but students also appear to appreciate the quiet, comfortable spaces offered by libraries.

MR had the fewest numbers of respondents respond positively to this question. It is not entirely clear why this is the case, but a combination of design and high occupancy levels make a plausible case. This library has the fewest computers, and one of the lowest numbers of seats per FLE (see table 1). MR is also the library with the highest occupancy levels (when numbers of individuals observed during each seating sweep are compared to total numbers of seats available, data not shown). In addition to occupancy levels, design may also affect student evaluation of the space. GM, ST, and RD all have separate floors with areas designated for quiet study. LC, though all on one floor, has low ceilings and inner walls, allowing for more effective zoning. MR has one level, high ceilings, and few space dividers, making noise containment less effective. Quiet study areas have been established at this library, but some of those areas are located beside louder areas with no sound barriers or baffling. A plausible explanation then for MR's low rating as a place to study alone may be a combination of design and occupancy levels, which means seats in a preferred study area are not always available.

Students are aware of what qualities make for an effective study environment for them personally, with needs varying from person to person. For example, some respondents indicated that they sometimes found it difficult to study in the library because of distractions such as friends, others talking, people talking on cell phones, groups discussing projects, and social software utilities such as Facebook. Contrarily, many listed noise as something that actually helped them to concentrate: "it's easy to settle into the working mode right away in the library, no matter where I sit, or who I'm near. I like the buzz of voices as well. It helps me concentrate." Individuals mentioned several qualities that are specific to the library and wouldn't necessarily be available in other spaces, such as access to resources (including library staff, books, the Internet, electrical plug-ins, and so on), a quiet space, behavior enforcement, and the communal study atmosphere. The library is not the only place available for individual study at these academic institutions; however, many respondents appear to appreciate these spaces because of these additional attributes that make it more than just a place with room to spread out one's books and computer. 


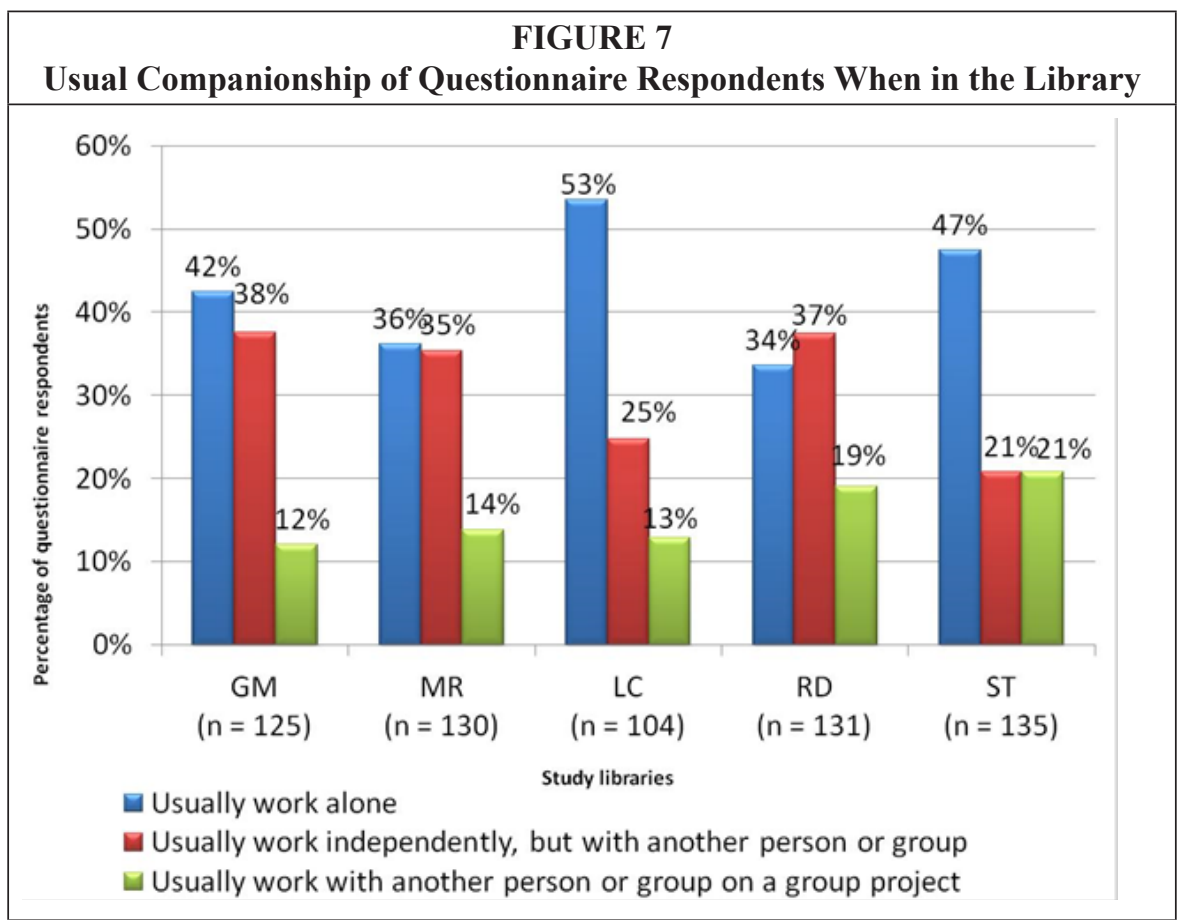

What may be surprising considering the noise complaints made by some respondents is that most students reported that they usually worked alone at the library (see figure 7). This agrees with previous research, where observations of academic library users indicated that they were far more likely to use the space alone rather than in a group. ${ }^{35}$

\section{Library as a Place for Group Work}

When asked whether the library was a good place to do group work, respondents were almost evenly split between those who said it was and those that said it only sometimes was, while very few indicated that it was not at all a good place to do group work (see figure 8). Responses to this question varied considerably between libraries. It may be that group study rooms play an important role in students' opinions about the library as a group study space; the institutions that provided the most dedicated group study space (see table 1) were also much more likely to be rated as good places to do group work. Although they contradict aspects of the results reported by Crook and Mitchell, ${ }^{36}$ Silver's findings provide support for this hypothesis; he concluded that collaborative spaces in an academic library were being used as intended in the design and were succeeding in supporting collaborative learning. ${ }^{37}$ It seems, however, that group rooms are not necessarily required to create a library that successfully supports group study. Despite its very low number of group rooms, observations of a relatively larger number of users working in groups indicate that ST succeeds in being fairly successful in supporting group study (see table 8). This library has two floors, one designated for quiet study and the other allowing conversation. It may be that this design helps to support a multiplicity of uses despite the low number of group rooms.

In analyzing the comments corresponding to the library as a place for group work, respondents were most likely to cite the group study rooms, and then furniture such 


\begin{tabular}{|l|c|c|c|c|c|c|}
\hline \multicolumn{7}{|c|}{ TABLE 8 } \\
\hline $\begin{array}{l}\text { Group } \\
\text { Size }\end{array}$ & $\begin{array}{c}\text { GM } \\
(\mathrm{n}=3,141)\end{array}$ & $\begin{array}{c}\text { MR } \\
(\mathrm{n}=2,077)\end{array}$ & $\begin{array}{c}\mathrm{LC} \\
(\mathrm{n}=712)\end{array}$ & $\begin{array}{c}\mathrm{RD} \\
(\mathrm{n}=1,711)\end{array}$ & $\begin{array}{c}\mathrm{ST} \\
(\mathrm{n}=1,627)\end{array}$ & $\begin{array}{c}\text { Total } \\
(\mathrm{n}=9,268)\end{array}$ \\
\hline 2 & 18 & 11 & 15 & 17 & 16 & 16 \\
\hline 3 & 8 & 8 & 7 & 9 & 8 & 8 \\
\hline 4 & 4 & 5 & 2 & 7 & 6 & 5 \\
\hline 5 & 3 & 2 & 1 & 2 & 3 & 2 \\
\hline 6 and Up & $<1$ & 2 & 0 & 1 & 2 & $<1$ \\
\hline All Groups & 32 & 26 & 25 & 35 & 33 & 31 \\
\hline
\end{tabular}

as large tables, and finally ample availability of space, as the reasons why the library was a good place for group work. It is interesting that some individuals felt the library was a good place for group work because it was generally a loud place and so there was less need to be quiet, reflected in comments such as "[the library has] loud volumes, [I] don't have to be considerate." Other informative comments referred to the ability to work in an environment that contained all the resources needed, where talking was permitted, and that everyone could access easily: "It is an easy place to meet, with a vibe that tends to promote being on task."

Most respondents who indicated that the library was only sometimes a good place to do group work indicated that their reasons had to do with availability of group study rooms or other group workspace. Others indicated that at times the library could be too loud and/or that they were concerned about being considerate to others working in

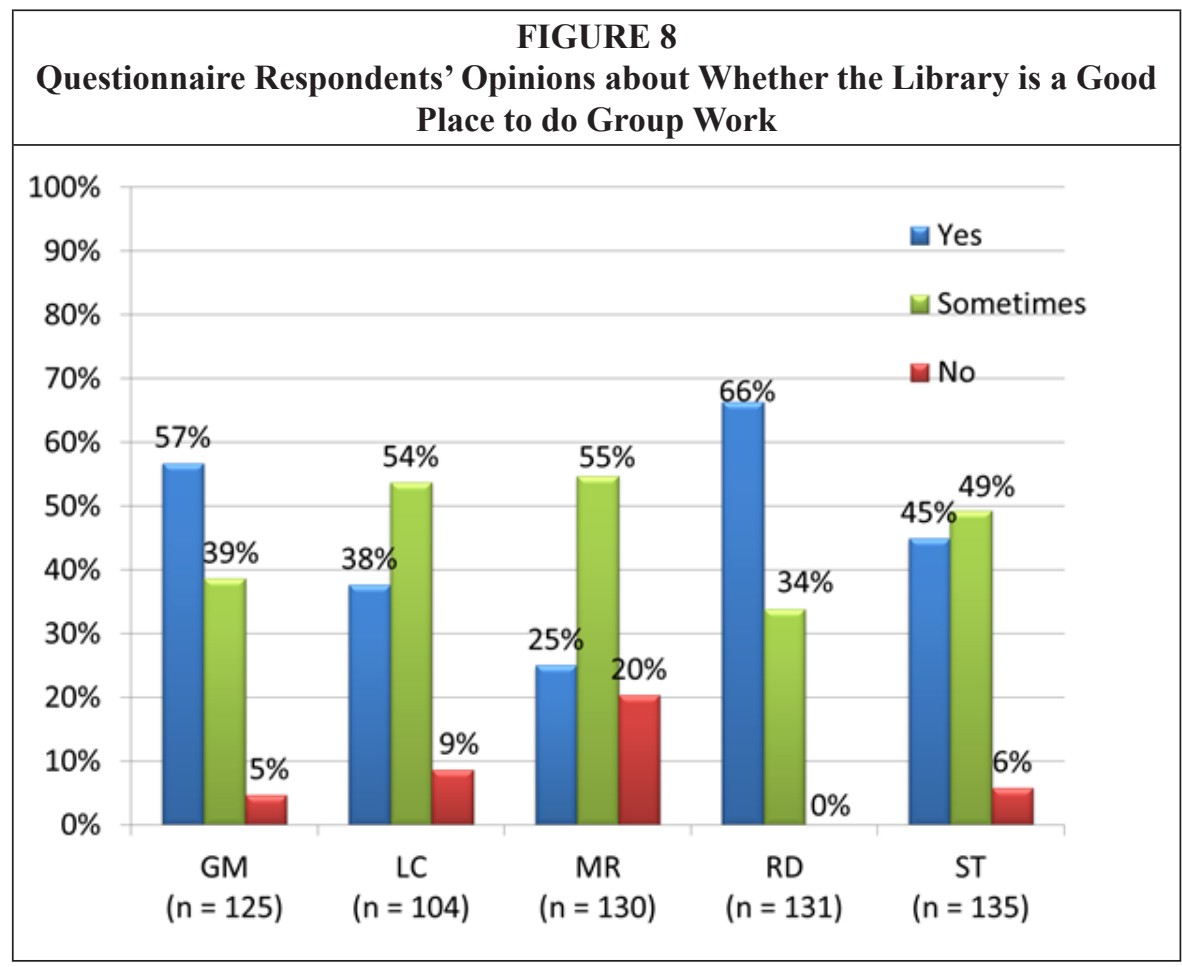


the library. Although few respondents indicated that the library was not a good place to do group work, the most common reasons cited, again, were noise and availability of suitable group workspaces. It is notable that some respondents thought the library was not a suitable place for group work at all: "Group work should not be done in library as you need to be quiet."

\section{Choosing a Spot to Sit in the Library}

When students were asked why they chose to sit in the spot they had chosen on the day the questionnaire was distributed, two responses, quiet and availability, were by far the most common, with each given by approximately one quarter of respondents. A few respondents indicated they selected their seat at random; but patrons indicated more commonly that, because the library was crowded or the more popular locations were already full, they had to take whatever seat was available. For example, one patron stated that "it was pretty much the last spot available" and another, "mainly because all group study rooms were full, I don't prefer this location but I know it's quiet and I have a table to myself."

Other reasons for selecting a particular location in the library included the desire to sit:

- in an isolated spot

- with a friend or group who was already there

- in a spot with ample workspace to spread out belongings

- near resources that may be needed

- near a window

- near an electrical outlet or in an area with wireless or network access

- $\quad$ in an area that permitted talking

- in a usual spot

A third of respondents indicated that the spot where they had chosen to study was somehow better than other places to study, and the most common reason identified was quiet: either the location was quieter than other spots or it was designated a quiet spot. Though many respondents complained about the noise of the libraries, it appears that many are successfully finding places to sit that are quiet.

Some patrons have very specific ideas about the types of spaces where they like to work. For example one patron succinctly described her reasons for choosing the particular carrel where she was sitting because it was "Bright, there's power. Alone but not so enclosed as the small brown cubicles. More space than small cubicles but not as loud as tables." Another makes choices depending on the type of work he needs to accomplish; on this day he needed a "...table to spread books out. Not intense studying [for example] for an exam or else [I] would have chosen to sit where others socializing would not bother me." The library serves different purposes for individuals on any given day; previous research has found that, depending on the purpose of their visit, students preferred different settings in the library. ${ }^{38}$

\section{Having a Favorite Place in the Library}

Just over half of questionnaire respondents reported having a favorite place in the library (58\%) (see figure 9). Results indicate that most people think of quiet spots away from others when they describe their favorite library location. In this study, when asked what qualities made for a favorite spot, noise level (mentioned by about half) was by far the most common factor affecting preference. A very few respondents indicated they liked to have some noise, but the vast majority said the best quality of their favorite spot was the quiet. Many also mentioned isolation or being removed from other people. 


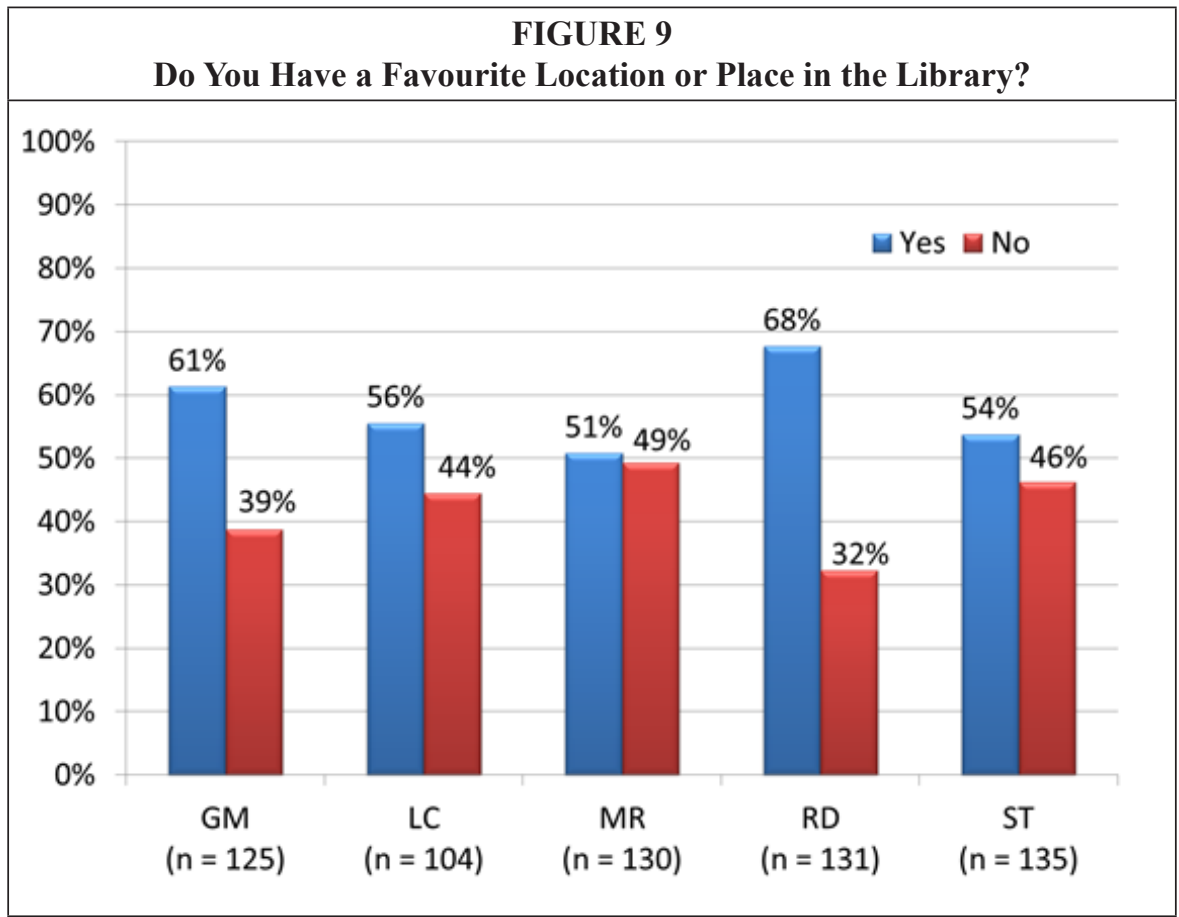

Windows and lighting are also very important aspects of favorite library locations. About a fifth of this subset of respondents identified windows, natural light or a view outside as a factor that made a spot their favorite. These qualities created a relaxing environment for respondents, and some said it helped them to recharge or regroup to stop and look out a window while studying: "I love looking out the windows when I need a break. I get to see lots of people I know."

Other common reasons for a place being described as a favorite are that it:

- promotes concentration (often due to other factors such as the quiet or lighting)

- $\quad$ is comfortable (for example, due to soft chairs)

- is spacious (lots of room to spread out books on a large table, for example, or because of openness of area)

- offers access to resources such as books or library staff

- offers access to electrical outlets or the Internet

\section{Meaning of the Library to Its Users}

Johnathan Hunter and Andrew Cox, in a study examining informal learning spaces, report that students consider background atmosphere as vital when selecting a space to study. ${ }^{39}$ Our study reveals similar results; when asked about the meaning of the library space for them, the most common response-given by almost one quarter of respondents - was an appreciation of the atmosphere in the library. Others commented on the library as a good place to study or relax or simply described it as a good place without specifying any further. A few individuals expressed a strong sense of attachment to the library, describing it as their "home away from home," as being "a vital part of [their] college experience," or simply as "awesome." Some respondents provided details about what aspects of the library made them appreciate it: "Excellent library. There are always available staff, resources for schoolwork, and always people who you can hang out with or get help from." 
Not all respondents felt an attachment to the library: "It's a library, it has no emotional meaning to me. It's a place of and for reference of people and materials. It's like a place of business, it's not a hangout" and "It sometimes scares me because I don't totally know how everything works/where everything is so I avoid it (not the best)."

Opinions of the academic library are as varied as the people who use it. Some feel passionate about these spaces, some criticize them, while others are neutral. A library can never expect to fully please all its users (especially considering that opinions are often contradictory!), but we can listen as users express their needs and adapt space and services where possible.

\section{Conclusion}

It has been argued that the increasing availability of information in a digital format creates a major challenge for academic libraries as physical spaces. ${ }^{40}$ This study and others show that, when library use is evaluated in terms of the physical use of the library, the situation in academic libraries is less clear than falling reference and circulation statistics might indicate.

We show that there are many similarities across the different types of academic libraries studied here: community colleges, undergraduate universities, and technical institutes. Although for the most part our results reveal that these libraries are being used in remarkably similar ways, there was some indication that the type of institution served may impact how users use the space. Users of the two university libraries were more likely to come to the libraries with the main purpose of consulting the library's print materials. Our results indicate that design and usage rates may also affect how users evaluate the activities that a library space can support. At MR, a very busy library with a design that limits the ability to control noise, users were much less likely to rate the space as a good place for individual study.

Our research also highlights the important role that library design plays in how a library is perceived by its users: for example, how well a library supports group versus individual work. Libraries are expected to be able to accommodate both types of work; and some libraries (for example, single-floor libraries, libraries without interior walls, or libraries lacking sound baffling) may be hampered in meeting this multiplicity of needs. With this in mind, it is important for libraries to consider carefully and attend to the needs of both groups and individuals, ensuring adequate choice when it comes to library spaces.

What the library literature wants and needs is a way to clearly demonstrate a link between libraries and learning. It is not an easy connection to make explicit. Many studies have shown what students are doing in the library, but the question remains "are they learning?" In this study, we are unable to correlate grades with time spent in the library - though others have been able to connect use of resources to academic success. Stone and Ramsden found a statistical relationship between academic achievement and both book borrowing and electronic resource use, although not with physical library entries. ${ }^{41}$

When students choose the library as a place to work on academic activities, they are choosing to place themselves in a setting that connects information to the social experience of learning. ${ }^{42}$ According to Kelly, Andrews, and Adams, social learning spaces such as the library foster social interaction between students and promote the development of a sense of belonging and community, all of which increase student engagement. ${ }^{43}$ Add to this the existing evidence that use of library facilities may be associated with student retention ${ }^{44}$ and persistence ${ }^{45}$ and there exists the opportunity for libraries to demonstrate value and alignment with institutional goals. 
Library visits alone may not be enough to influence academic achievement; rather, what seems to matter more is how a student uses the library when he or she is there. If, as Stone and Ramsden suggest, there is a correlation between resource usage and better grades, it would behoove the library to find ways to increase use of electronic and print resources by students. In our study, we show that students are already in the library engaged in academic pursuits, which presents a ripe opportunity for libraries to potentially increase student success through in-house promotion of resources and advertisement of their link to better grades. This also offers an interesting avenue for further research.

We are able to demonstrate that the library users we studied are likely to be good students and that that they are likely to be completing a large proportion of their academic work in the building. We also show that students continue to visit their libraries, that they see them as scholarly destinations, and that their primary purpose in visiting is to engage in scholarly work. They value the library for its proximity to the resources they need to do their work, for its communal academic atmosphere, for the convenient setting it offers for engaging with peers, and (when they can find it) for its quiet. Is this evidence of learning? Students are certainly coming with the goal of learning and are engaging in learning behaviors while they are there. We argue that students perceive the combination of setting, resources, and community that the library provides as an incubator for learning and that, by virtue of being among these things, they believe they will learn. As Foster explains it, students want to be in a "place with the scholarly gravitas that the library affords." 46 We are wise to pay close attention to the gravitas we foster within our four walls.

\section{Appendix 1: Student Questionnaire}

\section{Part A. About how you use the library}

1. When you come to the library to do schoolwork, which do you do most often?

Work or study by yourself

Work or study independently, but with another person or group

Work or study with another person or a group on a group project

I do not come to this library to do schoolwork

Other (please explain below)

2. Think of all the schoolwork that you do outside of class time. What percentage of that work do you estimate that you do in this library?

$0 \%$

Less than $25 \%$

$26 \%-50 \%$

$51 \%-75 \%$

$76 \%-100 \%$

3. How frequently do you visit this library?

Several times a day

Once a day

Several times a week

Once a week

About once a month

About once a semester

It varies (please explain below)

Other (please explain below) 
4. How long do you usually spend in the library?

Less than 15 minutes

15-30 minutes

31-60 minutes

$1-2$ hrs

More than 2 hours

It varies (please explain below)

Other (please explain below)

5. Is this library a good place to work by yourself?

Yes

No

Sometimes

a. Please explain your response.

6. Is this library a good place to do group work?

Yes

No

Sometimes

a. Please explain your response.

7. Please check the box(es) beside any activities that you have done in this library in the past year.

Worked on schoolwork using the library computers

Worked on schoolwork using a laptop

Borrowed or returned library materials

Physically searched for information (that is, in the bookshelves)

Read or studied print materials from the library

Read or studied print materials that you brought with you

Used a group study room

Got help from library staff

Used the printers/photocopiers

Attended a library instruction session or workshop or tour

Socialised in person (that is, chatting with friends)

Socialised online (for example, by using Facebook or e-mail)

Ate

Drank

Took a nap

Other (please list them below)

a. Please circle the main activity (above) that brought you to the library today. If it is not listed please write it in below.

\section{Part B. About the place you chose to sit in the library today}

Only answer the questions in this section if you have chosen a place to sit in the library today. If not, skip to Part $C$.

8. Why did you pick this specific location to sit in the library today?

9. Is there anything about this location that makes it better or worse than other spaces for the activities you are doing in the library today? Please explain.

Yes

No

Not sure 


\section{Part C. Your opinions about the physical space}

10. Do you have a favorite location or place in this library?

$\square$ Yes

No (continue on to question 11)

a. If yes, what place is it?

b. What is it about that place that makes it your favorite?

11. Please share any other comments that you have about how you use this library, what this library means to you, or what you think about it as a physical space.

\section{Part D. A few questions about you}

12. Please check the box beside the category that matches your GPA (grade point average) last semester. If this is your first semester at this institution estimate what your GPA will be at the end of the semester

$\begin{array}{llll}\square & <1(\mathrm{~F}) & & 3.7-4(\mathrm{~A}) \\ \square & 1-1.6(\mathrm{D}) & \square & \text { Don't know } \\ \square & 1.7-2.6(\mathrm{C}) & \square & \text { I prefer not to answer this question } \\ \square & 2.7-3.6(\mathrm{~B}) & & \end{array}$

13. What is your gender (sex)?

14. Please select the box beside the age category to which you belong.

$\begin{array}{lll}\square & 0<18 \text { yrs } & \square \quad 31-40 \text { yrs } \\ \square & 18-24 \text { yrs } & \square \quad 41-50 \text { yrs } \\ \square & \text { 25-30 yrs } & \square\end{array}$

15. How many semesters have you been studying at this institution?
$\square \quad 0 \quad \square \quad 5$
$1 \quad \square 6$
$2 \quad \square 7$
$3 \quad \square \quad 8$
$4 \quad \square \quad$ More than 8

16. Please check the box beside your program of study.

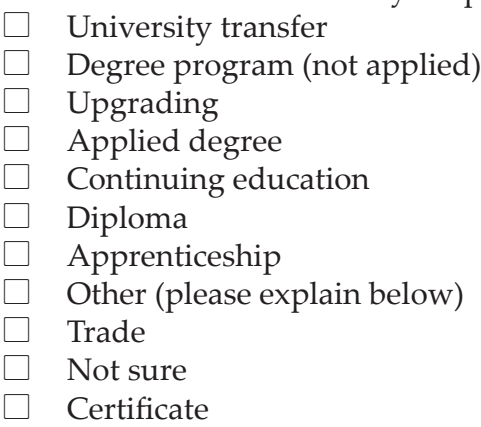

17. What is your topic of study? Which degree, diploma, trade, etc. are you studying?

18. Please share any other comments you have about this library or about this questionnaire. 


\section{Appendix 2: Seating Sweep Form (Sample)}

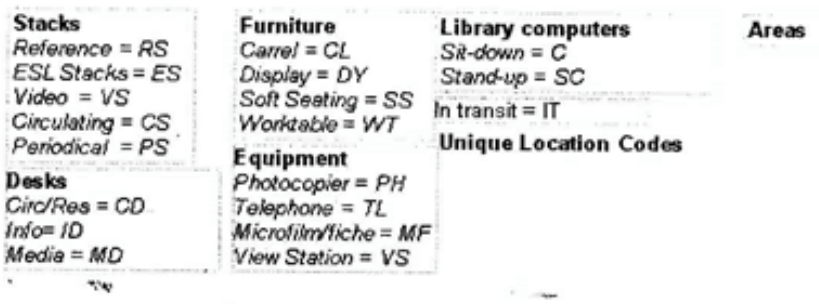

Time, Date, Library, Area of the library: $930 \mathrm{am}$. oct 23, MRU, Study Area

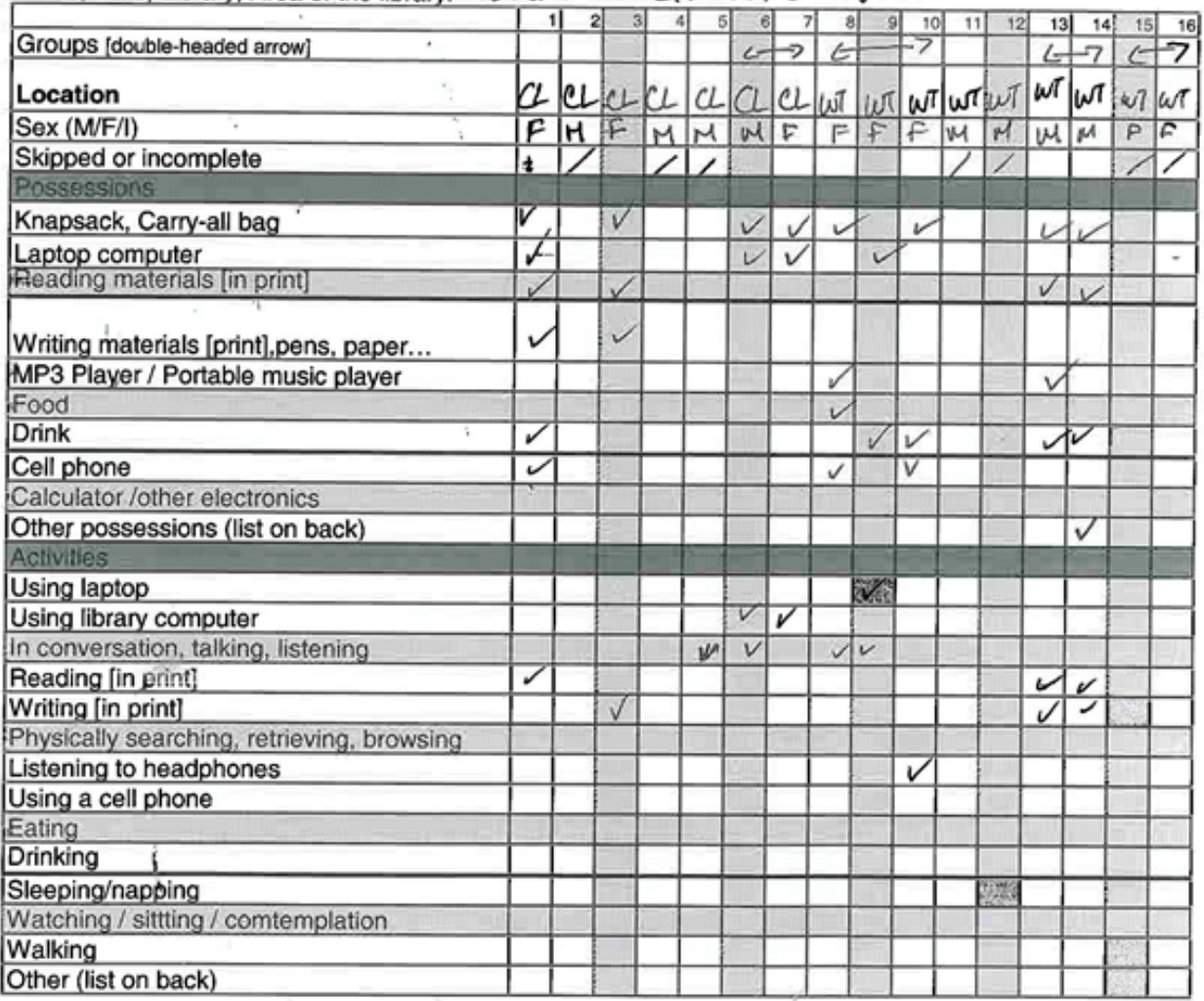




\section{Notes}

1. Charles Martell, “The Elusive User: Changing Use Patterns in Academic Libraries 1995 to 2004," College and Research Libraries 68, no. 5 (2007): 435-44.

2. John J. Regazzi, “U.S. Academic Library Spending, Staffing and Utilization during the Great Recession 2008-2010," Journal of Academic Librarianship 39, no. 3 (2013): 217-22.

3. Scott Bennett, "Libraries and Learning: A History of Paradigm Change," portal: Libraries and the Academy 9, no. 2 (2009): 181-97.

4. Ibid.

5. D.A. Nitecki, "Space Assessment as a Venue for Defining the Academic Library," Library Quarterly 81, no. 1 (2011): 27-59.

6. Paul Temple, "Learning Spaces in Higher Education: An Under-researched Topic," London Review of Education 6, no. 3 (2008): 229-41; Studying Students: The Undergraduate Research Project at the University of Rochester, eds. Nancy Fried Foster and Susan Gibbons (Chicago: American Library Association, 2007); Studying Students : A Second Look, ed. Nancy Fried Foster (Chicago: American Library Association, 2013); EunYoung Yoo-Lee, Tae Heon Lee, and LaTesha Velez, "Planning Library Spaces and Services for Millennials: An Evidence-Based Approach," Library Management 34, no. 6 (2013): 498-511; Susan E. Montgomery, "Library Space Assessment: User Learning Behaviors in the Library," Journal of Academic Librarianship 40, no. 1 (2014): 70-75.

7. Charles Crook and Gemma Mitchell, "Ambience in Social Learning: Student Engagement with New Designs for Learning Spaces," Cambridge Journal of Education 42, no. 2 (2012): 128.

8. Linda Bedwell and Caitlin Banks, "Seeing Through the Eyes of Students: Participant Observation in an Academic Library," Partnership 8, no. 1 (2013): 1-17; Joanna Bryant, Graham Matthews, and Graham Walton, "Academic Libraries and Social and Learning Space: A Case Study of Loughborough University Library, UK," Journal of Librarianship \& Information Science 41, no. 1 (2009): 7-18; Montgomery, "Library Space Assessment," 70-75.

9. Crook and Mitchell, "Ambience in Social Learning," 128; Montgomery, "Library Space Assessment," 70-75; Doug Suarez, "What Students Do When They Study in the Library: Using Ethnographic Methods to Observe Student Behavior," Electronic Journal of Academic and Special Librarianship 8, no. 3: Conclusion.

10. Lawrence T. Paretta and Amy Catalano, "What Students Really Do in the Library: An Observational Study," Reference Librarian 54, no. 2 (2013): 157-67.

11. Suarez, "What Students Do," Conclusion; Bryant, Matthews, and Walton, "Academic Libraries and Social and Learning Space," 16.

12. Nancy Fried Foster, "Designing Academic Libraries with the People Who Work in Them," in Studying Students : A Second Look (Chicago: American Library Association, 2013), 115; Suarez, "What Students Do," Conclusion.

13. Jeffrey T. Gayton, "Academic Libraries: 'Social' Or 'Communal'? The Nature and Future of Academic Libraries," Journal of Academic Librarianship 34, no. 1 (2008): 60.

14. Bedwell and Banks, "Seeing Through the Eyes of Students," 10.

15. Yoo-Lee, Lee and Velez, "Planning Library Spaces and Services for Millennials," 509.

16. Allyson Washburn and Sheila C. Bibb, "Students Studying Students: An Assessment of Using Undergraduate Student Researchers in an Ethnographic Study of Library Use," Library E Information Research 35, no. 109 (2011): 55-66; Silas B. Marques,"What Students Really Want: Library as Place at Andrews University," IATUL Annual Conference Proceedings, no. 35 (2014): 1-2.

17. Ruth Vondracek, "Comfort and Convenience? Why Students Choose Alternatives to the Library," portal: Libraries and the Academy 7, no. 3 (2007): 292.

18. Susan Gordon-Hickey and Trey Lemley, "Background Noise Acceptance and Personality Factors Involved in Library Environment Choices by College Students," Journal of Academic Librarianship 38, no. 6 (2012): 365-69.

19. Paretta and Catalano, "What Students Really Do"; Howard Silver, "Use of Collaborative Spaces in an Academic Library" (doctoral thesis, Simmons College, 2007), available online at http:// digitalcommons.bryant.edu/cgi/viewcontent.cgi?article=1000\&context=library_misc [accessed 12 August 2014]; Kathleen M. Webb, Molly A. Schaller, and Sawyer A. Hunley, "Measuring Library Space Use and Preferences: Charting a Path toward Increased Engagement," portal: Libraries and the Academy 8, no. 4 (2008): 407-22, doi:10.1353/pla.0.0014.

20. Yoo-Lee, Lee, and Velez, "Planning Library Spaces," 510.

21. Francine May and Alice Swabey, "Libraries as Learning Spaces: Exploring How Students Make Use of the Physical Space in Academic Libraries" (York, U.K.: University of York, 2012).

22. Graham Stone and Ellen Collins, "Library Usage and Demographic Characteristics of Undergraduate Students in a UK University," Performance Measurement and Metrics 14, no. 1 (2013): 25-35; Rachel Applegate, "The Library Is for Studying: Student Preferences for Study Space," 
Journal of Academic Librarianship 35, no. 4 (2009): 341-46.

23. Graham Stone and Bryony Ramsden, “Library Impact Data Project: Looking for the Link between Library Usage and Student Attainment," College \& Research Libraries 74, no. 6 (2013): 546-59.

24. Snunith Shoham and Nurit Roitberg, "From Electronic Library to a Learning Center in the Academic Library: Integrating Traditional and New Uses in the Library Workstation," Journal of Academic Librarianship 31, no. 4 (2005): 339-46.

25. Silver, "Use of Collaborative Spaces."

26. Anne Lehto, Leena Tolvonen, and Mirjna Livonen, "The Impact of University Library as Space and Place: Best Practices in Tampere University Library" (paper presented at the IFLA satellite meeting, Turin, Italy, Aug. 2009); Daniel S. Dotson and Joshua B. Garris, “Counting More Than the Gate: Developing Building Use Statistics to Create Better Facilities for Today's Academic Library Users," Library Philosophy \& Practice (Oct. 2008): 1-13.

27. Paretta and Catalano, "What Students Really Do," 164.

28. Paretta and Catalano, "What Students Really Do," 163.

29. Lehto, Tolvonen, and Livonen, "The Impact of University Library as Space and Place."

30. Lehto, Tolvonen, and Livonen, "The Impact of University Library as Space and Place"; Dotson and Garris, "Counting More Than the Gate."

31. Webb, Schaller, and Hunley, "Measuring Library Space Use and Preferences."

32. Ibid.

33. Gayton, "Academic Libraries: 'Social' Or 'Communal'? "

34. Scott Bennett, "First Questions for Designing Higher Education Learning Spaces," Journal of Academic Librarianship 33, no. 1 (2007): 14-26.

35. Webb, Schaller, and Hunley, "Measuring Library Space Use and Preferences"; Lehto, Tolvonen, and Livonen, "Impact of University Library as Space and Place."

36. Charles Crook and Gemma Mitchell, "Ambience in Social Learning: Student Engagement with New Designs for Learning Spaces," Cambridge Journal of Education 42, no. 2 (2012): 128.

37. Silver, "Use of Collaborative Spaces."

38. Robert Sommer, "The Ecology of Study Areas," Environment and Behavior 2, no. 3 (1970): 271-80; Elizabeth M. Williams, "Studying Students: The Undergraduate Research Project at the University of Rochester," College \& Research Libraries 69, no. 3 (2008): 290-92.

39. Jonathan Charles Hunter and Andrew Cox, "Learning over Tea! Studying in Informal Learning Spaces," New Library World 115, no. 1/2 (2013): 4.

40. Scott Bennett, "The Choice for Learning," Journal of Academic Librarianship 32, no. 1 (2006): 3-13; Pongracz Sennyey, Lyman Ross, and Caroline Mills, "Exploring the Future of Academic Libraries: A Definitional Approach," Journal of Academic Librarianship 35, no. 3 (2009): 252-59.

41. Stone and Ramsden, "Library Impact Data Project."

42. Bennett, "The Choice for Learning."

43. Kelly E. Matthews, Victoria Andrews, and Peter Adams, "Social Learning Spaces and Student Engagement," Higher Education Research \& Development 30, no. 2 (2011): 105-20.

44. Brent Mallinckrodt and William E. Sedlacek, "Student Retention and the Use of Campus Facilities by Race," NASPA Journal (National Association of Student Personnel Administrators) 46, no. 4 (2009): 566-72; Ralph E. Russel et al., "The Relationship of Documented Library Use to Academic Achievement, Program of Study and Progress toward a Degree" (paper presented at the Annual Forum of the Association of Institutional Research, Denver, Colo., May 1982); J.D. Grallo, M. Chalmers and P.G. Baker, "How Do I Get a Campus ID? The Other Role of the Academic Library in Student Retention and Success," Reference Librarian 53, no. 2 (2012): 182-93.

45. William D. Churchill and Stanley I. Iwai, "College Attrition, Student Use of Campus Facilities, and a Consideration of Self-Reported Personal Problems," Research in Higher Education 14, no. 4 (1981): 353-65.

46. Foster, "Designing Academic Libraries with the People Who Work in Them," 115. 